\title{
Experiences of older Polish migrants in the United Kingdom - questioning the older migrants' image in migration literature
}

The experiences and migration strategies of senior migrants differ significantly from those of their younger counterparts. However, since migration flows are dominated by younger migrants, the recent Polish migration discourse tends to present the younger migrants' perspective. This article addresses this research gap by exploring the migration experience of older Polish migrants to the United Kingdom (UK). The types of older migrants currently living in the UK are discussed: namely those who have lived in the UK for several decades and those who have migrated late in life. The experiences and attitudes of both groups are then explored and compared in order to expose several assumptions concerning older migrants: the immobility of seniors; the vulnerability of older migrants; and seniors migrating exclusively as part of care networks. The article is based on qualitative research conducted in the UK in 2005-2009 and in 2017.

Keywords: senior migrants, elderly migrants, Polish migrants, care, aging in place, post-accession migrants

\section{Introduction}

The aim of this article is to explore the migration experiences of older Polish migrants to the United Kingdom (UK) and to question several assumptions about migration and old age. The UK is currently, after Germany, the largest destination country for Polish migrants. Since the UK opened its labour market for Polish citizens in 2004, it has had the largest share of post-accession migration.

${ }^{1}$ Corresponding author: abielewska@swps.edu.pl 
Recent Polish migrants to the UK are usually pictured as young. However, although young migrants dominate migration flows, experiences of older migrants should not be excluded from the public discourse as to do so would ignore the "different motivations, decision-making processes, and economic, environmental, societal and welfare impacts" (Warnes and Williams, 2006:2) of this group. The growing number of foreign-born residents aged 55 and older observed throughout Europe between 2010 and 2015 (Ciobanu et al., 2017) shows that the aging of society affects migration flows. The increasing body of work on elderly and senior migrants in Europe - which includes not only articles but books (e.g. Horn and Schweppe, 2016, Karl and Torres, 2016, Walsh and Näre, 2016) and special issues of journals (e.g. JEMS 2017, 43(2) or 2006, 32(8)) - shows researchers' growing awareness of older migrants. However, empirical studies of Polish migration to the UK usually focus on the experiences of young adults (e.g. Lopez Rodriguez, 2010, Datta, 2008; Ryan et al. 2008), who are presented as representing the general experience of "migrants". Works on transnational families may consider more mature migrants but these are still not old (Pustułka, 2015, Kileky and Merla, 2014; White, 2011). If seniors are discussed in the context of migration, they are usually presented as immobile family members of migrants and analysed in the context of their care needs (i.e. Kordasiewicz et al, 2017; Kiełkowska et al. 2016; Barglowski et al., 2015; Krzyżowski, 2013). Older migrants appear in a small body of work on post-war migration who aged in place (Bielewska, 2012a and 2012b, Garapich 2008, Temple, 2001). Seniors who migrate later in life to the UK have not yet been the subject of deeper interest among Polish migration researchers, with the exception of a few economic and demographic researchers (i.e. Pemberton and Scullion, 2013 or Kałuża -Kopias, 2015). However, the Office for National Statistics (2017) data show that over 48,000 Poles aged 50+ who arrived at different times currently live in the UK and their number can be expected to grow due to the aging of society.

This article is constructed around the internal heterogeneity of this group and especially around the strong differences in experiences between migrants aging in place - those who migrated early in life and reached old age in their destination country - and late-life migrants who were already seniors when they migrated (Ciobanu et al., 2017, Warnes and Williams, 2006). It also shows the difference between the younger and older sub-groups of older migrants, namely the third age group that contains migrants between 60 and 70 and the fourth age group that consists of migrants over 70. In the case of my research, migrants who age in place are represented by Polish post-war migrants, who are also the oldest seniors. The second group are post-accession migrants who are late-life migrants and are the younger group of seniors. The characteristics of both groups are briefly described, the research methodology is then outlined and the analysis of the research data is presented to provide context for discussing the image of older migrants in migration literature. By showing the diversity of the migration experiences of older 
Polish migrants this article questions the picture of senior migrants that emerges from care regime research and research on aging in place. The care regime literature presents seniors as immobile family members deserted by their migrant children or as grandparents who migrate (often circularly) to take care of grandchildren (Baldassar and Merla, 2013; Vullnetari and King, 2008; Plaza, 2000). The aging in place literature usually sees aging migrants as vulnerable, disadvantaged and socially excluded, aging out of space even if they have spent many years in the country, and sees place as static and closed (Lewis, 2009; Becker, 2003). By presenting the experiences of Polish older migrants, this article supports the argument that the picture of older migrants as always static, dependent care recipients and struggling to connect in a new place is incomplete (Johansson et al., 2013). It is also an argument for the use of an open conception of place in gerontology, a well-known idea in migration studies (Massey, 1992).

\section{Types of senior Poles in the UK}

The subjects of this paper are first generation Polish migrants to the UK aged at least 60 . These are referred to in the literature as "older migrants", "later life migrants" or "retirement migration" (Ciobanu and Fokkema, 2016; Warnes and Williams, 2006). The term "elderly" is no longer used as it may be perceived as offensive and referring only to the oldest group of seniors. In this article the term "older migrants" is used to describe both migrants who aged in their destination place and those who migrated as seniors. To distinguish the two groups, the former are called "senior migrants" while the latter are called "late-life migrants". Some researchers relate old age to the point of leaving the labour market (Warnes and Williams, 2006), others to reaching the legal retirement age (Kałuża Kopias, 2015). Most senior Polish migrants living currently in the UK arrived there as part of different waves of migration, mainly after the Second World War and after the accession of Poland to the EU (Okólski and Salt, 2014; Burrell, 2009). This article compares the migration experience of these two groups of migrants. Adopting the terminology defined above, post-war migrants are "senior migrants" and postaccession are "late-life migrants". The old age boundary in this research is 60, as the average age of retirement in Poland has varied around this number (57 in 2006, 60 in 2010, 61 in 2014 - Szukalski, 2014).

The post-war Polish migration consisted mostly of Polish soldiers who arrived in the UK during and after the Second World War, and civilians, mostly families of soldiers and displaced persons from German camps, who arrived between 1945 and 1950. Britain offered them free domicile and assimilation was facilitated by access to employment, vocational classes, English classes and ultimately British citizenship. The rate of naturalisation was a third by 1961 and two thirds by 1977 
(Scragg, 1986). Naturalisation can be seen as an attempt at assimilation, but a British passport also facilitated the migrants' visits to communist Poland (Bielewska, 2012a). In 1951 there were over 162,000 persons born in Poland resident in Britain (Burell, 2009). Currently post-war migrants represent the oldest group of Polish seniors in the UK. They migrated as children or young adults and have spent almost all their adult lives in the UK. It is the place where they worked, bought houses and raised children. The post-accession migrants arrived after Poland joined the European Union in May 2004 and Poles were granted the right to work without obtaining a work permit in the UK. Although by 2001 the population of Poles living in the UK had fallen to 58,000 (Okólski and Salt, 2014), by 2016 there were 911,000 (Office for National Statistics, 2017). Some seniors come to England to care for their grandchildren (20\% of the Polish population in the UK is under 15 - Office for National Statistics, 2017). Others arrive to improve their economic status after becoming unemployed later in life or because their Polish salary does not allow them to live a comfortable life.

\section{Methodology}

This paper presents the results of research on older Polish migrants in the UK. The analysis presents the findings of research on late-life migrants, conducted in 2017 and the findings of earlier research on Polish senior migrants in Manchester, undertaken between 2005 and 2009 (see Bielewska 2012a and 2012b). Data from the latter is presented from a new perspective. All interviews were conducted in Polish, and the names of the participants have been changed to protect their anonymity.

The 2017 research consists of netnographic research, including interviews with key people in the Polish community such as workers in Polish institutions and 10 interviews with 8 post-accession Polish migrants aged between 60 and 65 living in England, mainly London and Manchester. The interview sample included three men and five women diversified in terms of their education (two of them have higher education, others graduated from high schools or vocational schools) and personal situation. Two women were interviewed twice, first in the preliminary stage of research and later, after the research questions were defined. The interviewees came from cities and towns of central or western Poland. Most of them came to England as primary migrants to improve their economic situation, some to join their partner (two women) or to help with grandchildren (one woman). They were approached by the researcher with the use of social media channels or through the researcher's friends. The 2005-2009 research consisted of individual and group interviews with 17 post-war Polish migrants aged between 70 and 90 who lived in Manchester (Bielewska, 2012a) and were connected to the Polish community there. The sample included 10 female and 7 male migrants. The interviewees 
were diversified in terms of their education and family situation. The analysis of the interviews was conducted by thematic analysis to facilitate reporting of the experiences, meanings and reality of the participants (see Braun and Clark, 2006). The author immersed herself in the data by reading and re-reading the interview transcripts (Kvale 1996), then an open coding procedure was conducted, allowing categories and themes to emerge from the data (Saldaña 2012). Presenting experiences of 60-year-old late-life migrants and over 70-year-old senior migrants highlights the diversity of older migrants' experiences. The experiences of both groups of Polish older migrants are presented separately not in order to compare them but rather to show the diversity. The number of interviews is insufficient to build the full typology of older migrants' experiences, but it is enough to point to gaps in the current discourse on both post-accession migrants and older migrants.

\section{Situation of older Polish migrants in the UK}

The analysis is organized around the main themes emerging from the interviews. It is presented separately for senior migrants and late-life migrants because in spite of being older migrants these groups are too different to merge together and describe as one unit.

\subsection{Social life}

\section{Family situation of senior migrants}

The senior migrants are post-war migrants who arrived in England as young adults or as children and aged in place. England was where they started their own families and where their children were born. At the time of the interviews some of them had reached the age of 80 , when biological, psychological and social processes leading to irreversible breaking of biological and psychological balance may be strongly experienced (Staręga-Piasek et al., 1985; Kiełkowska et al, 2016).

Two main types of narratives emerge from the interviews with post-war migrants. The first focuses on the migrants living near their adult children and grandchildren and the second is built around loneliness. As Bielewska (2012a) explains, as a result of migration the families of post-war migrants in Manchester are usually limited to parents and children. Other relatives, such as descendants of their brothers and sisters, may live in their homeland or some other country. Therefore contacts between parents and children may be the only direct form of family life. Their houses are full of pictures that they use to evoke absent relatives; by talking about them, they express longing for their lost homeland and lost relatives. Migrants who enjoy having their adult children and grandchildren in close proximity 
may express the satisfaction of being useful and busy. Joanna who helps one of her sons by looking after his daughter says:

We are retired at the moment and we sit here but we don't have time for anything. I go to my son Alek's or I collect the child once a week from school, his little granddaughter, or I come here [a bingo meeting]. (Joanna, 76)

Even if some of them do not approve of their children's choice of spouse, they are still included in the nets of relationship which gives them the feeling of belonging. Those who do not have children or whose adult children have moved further away express a feeling of loneliness. The elderly migrants' solitude is a constant theme that appears throughout the interviews. Even those living with their spouses complain of the sadness caused by rare contact with children who have moved abroad. This is the case with Weronika and her husband, who feel deserted by their daughters:

The worst thing is that I have two daughters and one is in California and the other one went to Poland five years ago and said she wouldn't come back to England. A lawyershe finished studying law and then started working. She said she wouldn't come back for anything. It's because of the children and the schools. And she's lived for five years in Poland. She's very happy. But we have nobody here. (Weronika, 80)

Interestingly, the interviews show that migrants' children seem to be prone to mobility. Being raised in the myth of homeland may weaken their roots in their country of birth.

Loneliness is a common experience for senior migrants (Ciobanu and Fokkema, 2017; de Jong Gierveld, van der Pas and Keating 2015; Fokkema and Naderi, 2013). Ciobanu and Fokkema (2017) in their research on Romanian migrants show that a refuge from loneliness may be religion. However, the present research does not identify religion as a way Polish migrants manage loneliness. The senior migrants seem to search for company and a feeling of belonging in the Polish ethnic community rather than in religious gatherings. Religion is an important part of Polish identity for this group, but the group is organized around Polish ethnicity and not religious belonging (see Bielewska, 2012a). The role of the Polish ethnic community in the life of post-war migrants is explored later in this article.

\section{Family situation of late-life migrants}

Interestingly, loneliness does not appear as a theme in the interviews of Polish late-life migrants, which supports the observation of van den Broek and Grundy (2017) that migrants who stay abroad longer are lonelier than those who arrived recently. Being in their sixties, the late-life migrants are one generation younger than the senior migrants (post-war migrants). As their migration decision was 
quite recent, migration can be used by them as a way of leaving unpleasant family situations. A physical distance may just follow the emotional one.

Zbyszek: My family stayed in Poland.

Agnieszka: Do you visit them?

Zbyszek: In May it will be two years since I was in Poland. Well... My family turned stupid. Politics divided us, among other things. (Zbyszek, 60)

Migration may be a convenient way of escaping because it allows the avoidance of confrontation with family members (for a description of migration as escape from difficult family situations for younger Polish migrants see Urbańska, 2016). Migrants' relationships may officially continue with rare home visits for important family occasions while the physical distance allows them to live alone in their new location.

In my case, my husband stayed in Poland and I came here. I was very happy that he was there and he wasn't [happy]. And I'm not going back to him. Never. (...) And he sits there alone and I enjoy life. (Dorota, 60)

Additionally, staying abroad gives migrants personal freedom that they would not exercise in their place of origin. It is especially important for those who felt oppressed in Poland because of their age and gender. They see England as tolerant and liberating and argue that England offers them chances that would be unavailable in Poland.

Between us women, Poland is very stressful, especially for women. We don't have the same causes [of stress] here (...) I learnt here what it means to be a woman. (Dorota, 60)

Apart from those who use migration to separate themselves from their families, the sample also included those who came to the UK with their families. Since the literature on older migrants often describes late-life migrants as vulnerable, lonely and coming abroad to join their adult children (Ciobanu and Fokkema, 2017; Kilkey and Merla, 2014), it is worth stressing that the strategies of some late-life migrants are similar to family reunification migration observed since the 1960s and 1970s (Raghuram, 2004), where one partner (usually a man) migrates first and is later joined by the other partner and their children. Some of the late-life Polish migrants lost their jobs in their $40 \mathrm{~s}$ and 50 s and moved abroad to improve their economic situation. Later they facilitated their adult children's migration by offering them accommodation and helping them to find a job. These migrants do not fit into the vulnerable older migrant picture, showing that older migrants are a heterogeneous group and cannot be described solely from the care regime perspective. 
The narratives of late-life migrants show gender differences similar to those observed in the narrative of senior migrants. The post-accession female senior migrants, as with the post-war female migrants, focus their narratives on adult children and grandchildren, who are a less frequent and less developed theme amongst the male respondents. Women often stress that they live close to grandchildren and help with childcare. Surprisingly, my research participants do not live with their adult children. They explain they prefer to enjoy their freedom:

If I want, I could stay with my children but I prefer[to live] alone, to be on my own. Not to live with the children. Because, you know, small children, they cry. What do I need that for? [It is better] to just go there and leave. Never [to live with them]. (Janina, 65)

Single late-life migrants usually rent a room in a shared apartment. Those who migrate with their spouse rent a house or live in a council house. In contrast, senior migrants usually own the houses they live in.

When late-life migrants join their children in the UK, this does not necessarily mean the family has been fully re-unified, since other children may still live in Poland and, in most cases, so does the extended family.

\section{Social capital of senior migrants}

As mentioned above, the remedy for the lack of family life and loneliness for post-war migrants is the Polish diasporic community. As Bielewska (2012a) shows, the post-war Polish migrants in Manchester bought houses close to each other and to Polish institutions. For many members of the Polish community there was a time when the Polish Club was the everyday place for having lunch. Due to aging, the Polish community has decreased in size and the Club has closed down. Currently the social life of many post-war migrants is limited to sharing a meal in the parish building after Sunday mass and a weekly bingo meeting. Although some complain of the lack of gratitude of their peers for the community work they do, they are satisfied with the bonding networks (Putnam, 2007) they are part of.

A common theme of complaints in this group is contact with English society. They feel they do not have any meaningful contact with English neighbours anymore. As Bielewska (2012a) found, when the post-war migrants limit their social networks in a way typical of elderly people, weak ties (Granovetter, 1973) are cut first. In the earlier stages of life, in accordance with Putnam's (2007) and Ryan's (2008) theories, strong ties with other Poles do not exclude dispersed, weaker ties with the host society. High bonding capital might have been compatible with high bridging capital, and migrants who established strong, trusting relationships with their fellow migrants and who had the necessary language competence might have been able to use these skills to develop more extensive relationships with weak ties beyond their own ethnic group. However, ageing tends to limit 
a person's range of activity and when the weak ties with English society are cut first, the post-war migrants find themselves enclosed within the Polish ethnic community. At this stage contact with English neighbours is reduced to greetings (see Bielewska, 2012a).

This shows that the general rule of building relations with a place though an accumulation of repetitive practices, where the length of the process is correlated with the strength of the relationship, breaks down in the case of the older group of senior migrants. The repetition should produce the bonds with the place in the form of networks of stable relationships (Edensor 2006:528). However, post-war migrants who had built stable relationships at some point cut them off later in life. The critical time was identified by migrants as the moment of retirement.

We're divided from English people and we live only with Polish people. My English is now much worse than when I ran my office. When I ran my office it was perfect. (Tolek, 88)

The loss of English co-workers means deterioration in migrants' language skills and a further weakening of their ties with the English-speaking population. However, the majority of post-war migrants in Bielewska's (2012a) research never became fluent in English. They described their competence as "getting by" (Polish "radzę sobie"). The lack of fluency in English may be one of the causes of the mistrust toward English people noted by Bielewska (2012a). Combined with aging, which in itself can increase suspiciousness, this may result in the alienation of migrants who are not only remote from English society but also afraid of expressing their views:

English people are lovely but you have to know how to handle them. Englishmen will smile at you, stroke you, say you are beautiful but when you don't look ... oh God! ... But I will say nothing bad. I can't say because I live here. But you need to be very careful. I like English people but not too much. But I've lived here 40 years and I've managed with them and they with me. (Władka, 80)

As Bielewska (2012a) notes, the lack of English people in the social networks of post-war immigrants shows a problem with integration. In spite of living in the UK for 60 years they still feel more like guests who need to make a good impression rather than feel at ease with their hosts and be equal members of English society. The words "English society" are used here advisedly. The post-war migrants do not perceive the UK as a multicultural country. They settled there after WWII, before the big immigration waves from the former colonies. They observe the settlement of diverse immigrants in their neighbourhoods but this is a minor theme in the interviews. The host society from their narratives is an English one. It is a completely different society to that described by post-accession migrants. 


\section{Social capital of late-life migrants}

The late-life migrants differ from senior migrants in their attitude towards the Polish community. They need Polish institutions as their language competences handicap their ability to capitalize fully on the possibilities offered by the British society. The Polish community is therefore a mediator between them and British society rather than a place to cultivate Polishness. Faist (1996) noted that ethnic institutions are required facilitators of integration since they compensate primarily for a lack of cultural recognition, political powerlessness and economic failure of immigrants. However, in this case ethnic institutions are not used as alternative sources of positive identification since the reference group for postaccession migrants are their peers in Poland. Ethnic institutions are rather used to compensate for lack of social, cultural and economic capital as they translate and explain foreign reality. They are also a chance to find a new life partner and develop a network of friends. However, friends rarely appear in late-life migrants' narratives. They do not talk about having friends but nor do they mention a feeling of want or loneliness.

I have friends, but I'll admit honestly, at the beginning there were many of them and now everyone has their own life. Everyone brought their family and now it's a closed circle. There is a son, daughter, the same as with me. We meet from time to time for girls' nights out but...at the beginning it was more frequent and now everyone is busy. (Patrycja, 60)

While for senior migrants the Polish community is a substitute for family bonds, late-life migrants replace friends who were more important in the first stage of migration with family. It seems that migrants aging in place, who have spent most of their lives abroad, have a need to build ethnic institutions and bonding networks of friends, while late-life migrants who arrive late in life do not feel such a need. However, this may also be because senior migrants were, in this case, political migrants who were cut off from their homeland, while late-life migrants are economic migrants who can visit Poland any time and also have access to new technologies that may offer the feeling of co-presence (Baldassar, 2008 but see Ryan et al., 2015). They live in a more transnational way. The senior migrants who are the older group do not use this kind of media (Bielewska, 2012a).

The evaluation of contact with the English-speaking local population also differs between these two groups. Senior migrants are disappointed by their bridging networks (Putnam, 2007) but there is a group of late-life migrants who enjoy what they perceive as the English mentality, which they describe as politeness, general kindness and willingness to help:

I live in a 16 floor building and they're really very helpful. To help with something, to translate something. I can't complain. Everywhere I go they are very polite, even though 
I'm Polish, and it's said Poles are treated... I don't know. I've never met [anything bad] nor has my husband. (Maria, 65)

Late-life migrants also mention the positive attitude of the British population toward seniors:

They don't use words that hurt. Or maybe in English it doesn't hurt me so much. But I haven't noticed young people being rude. You can't compare it [to Poland]. Also they have a queen, an old lady, and they've learnt that old age is fine. They have it from childhood. And in Poland - no. I am sorry to say it about us. (Dorota, 60)

Their fascination with British society is partly a result of its diversity. They grew up in homogenous communist Poland and dreamed about the freedom and welfare of the world outside the Eastern bloc, but the borders were mostly closed.

In the 1980s I drove abroad, I saw how you live in France, how you live in Germany, how you live in Italy and I came back to this mean, sad country where people are enemies with each other, nobody says "good morning", nobody laughs and I always wanted to go abroad again as soon as possible, even for a few days, where the strangers greet each other. (Zbyszek, 60)

Evidently some late-life migrants treat migration as fulfilling their youthful dreams. Their late-life migration is often their first direct exposure to diversity and they are enchanted by it:

I liked people, I was interested in people, faces, characters. Not to mention the nationalities. To see the world, meet people, traditions. (Dorota, 60)

The polite greetings, considered a sign of distance by post-war migrants, are perceived by post-accession migrants as a highly appreciated sign of welcome. Where post-war migrants look for some sign of hidden meaning in English politeness, the post-accession migrants take it at a face value and enjoy the culture of British people, which they contrast with Polish rudeness.

Those whose migration was negotiated as part of a family strategy may have a less positive attitude toward their new location. This general attitude also affects their perception of British diversity:

They treat us differently. Generally they treat Lithuanians and Gypsies better than Poles. (...) And generally the atmosphere is not the same. Before this street... we had a very quiet street. (...). And now there are many Gypsies, Ciapaci [rude name for Indians and Pakistanis]. And music and noise. (Patrycja, 60)

Interestingly, the diversity of British society rarely appears in senior migrants' interviews. Aging in place, they may have gotten used to diversity and some of them 
also may have learnt to be "politically correct". Therefore they rather imply their dislike while the late-life migrants vividly express their fascination or feeling of fear and dislike of the multi-ethnic population.

Summarizing, the social life of senior migrants is organised around their families and the Polish community or in some cases is limited to care institutions. They complain of weakening ties with English society or enjoy the fact that they can live their life among co-natives. The media they use are the printed press, Polish television, phones and traditional post. The social life of late-life migrants is more complicated. They leave Poland to cut family ties or come to the UK to join their partner, children and grandchildren. They develop a network of Polish acquaintances because it offers them some feeling of security in the first stages of migration. Their contacts with the host society, even if limited to polite greetings, may be a source of joy for them. Senior migrants and late-life migrants share Polish institutions such as Polish churches and Polish clubs. However, the senior migrants are hosts and late-life migrants just users. Apart from Polish churches and Polish Saturday Schools, Polish institutions formed by post-war migrants are passed down to children born in the UK rather than new arrivals. The late-life migrants to an extent manage to learn new communication technology and use it to cultivate transnational links to their home country.

\subsection{Economic and political situation}

The economic situation is an important theme in the post-accession migrants' narratives but is almost absent from the post-war migrants' narratives. In contrast, the political situation is more significant for post-war migrants, though they describe it in past terms, as a part of their history. This difference may be explained by the circumstances leading to the decision to migrate. Post-war migrants are mostly political migrants who stayed abroad after WWII. For years the political situation meant they could not visit their homeland. The post-accession migrants moved recently and economic factors were very important in their decision-making process.

\section{Senior migrants}

The post-war migrants are aging in their destination place. Their migration took place so long ago that they do not spontaneously compare life in Poland with life in England anymore. If they talk about Poland they compare the country they left with the country Poland became, or the communist Poland they visited and the capitalist Poland now. It leads them to the conclusion that the Poland they knew does not exist anymore.

Emil: Poland doesn't look like how we remember. It doesn't look like the place I came from. Nothing can replace it .... I sometimes sit together with Lucyna, we look at all the 
things we achieved and I say, 'I would give it all up for my small house in Poland if it was still there'. But it isn't. (Emil, 80)

There is no reason to return. There is also no reason to analyse the economic and political situation in both countries in search of the best option. Migrants also feel that their "mobile time" belongs to the past. Even though they have visited Poland many times since the communist bloc collapsed in 1989, they have not thought about a permanent return. The period of such decisions is already over in their life. They could have gone back when they were younger but Poland was a communist country then and a return could have resulted in imprisonment. The current time is the time of old age and excludes migration. Senior migrants stress that they their stay in the UK has changed them and they are different people from their peers in Poland.

Their rejection of moving back to Poland could be a confirmation of the assumption in the aging in place literature that continuity is very important for older people (Peace et al., 2011; Wiles et al. 2011). However, there are many studies of middle class European pensioners who spend part of the year in sunbelt countries (Warnes and Williams, 2006; Breuer, 2005; Warnes et al., 2004). Similar lifestyle phenomena are also known in other developed countries (Ono, 2008). Polish senior migrants neither move to Poland permanently nor travel for prolonged visits. This may be the result of the unattractiveness of Poland for them or of the financial impossibility of keeping holiday houses in Poland. The interview data suggests that many Polish senior migrants need some kind of state support. Prompted, senior migrants admit that Poland, in their eyes, has nothing to offer to its old citizens. Even those who actively helped their country for years such as members of the ex- Combatant Association cannot expect anything in return. Tolek, when asked about the possibility of returning to Poland, expressed his resentment:

Now? What can an old man such as me do? What can I give Poland? I want to receive now (shouting). That's what needs to be said. I'm 80. I've worked for Poland all the time. Now I'd expect that somebody in Poland would take care of me, yes? That's what needs to be said. (Tolek, 88)

Another 82-year-old member of the Polish community in London says more directly:

Generally speaking, in old age I think care is better in England (...) in old age I need medicine for high blood pressure and cholesterol so I get them completely free and in Poland I would have to pay - even though I'm retired I'd have to pay. I live very comfortably here. (Romek, 82)

Romek divides help received in the UK into two categories: age-related and poverty related. He gladly receives the age-related help but he finds any suggestion that he might need benefits related to poor economic status offensive. Generally, the 
post-war migrants rarely speak about their economic situation. They feel they are in the UK as guests and position themselves as representatives of Poland. Therefore they want to make a good impression and are proud of being economically selfsufficient. As one of the post-war migrants said:

At my age I don't need anything anymore. I'm perfectly happy with my life. I've enough for my life, for bills, I don't need anything more. (Paweł, 80)

\section{Late-life migrants}

The late-life migrants who are post-accession migrants and arrive in the UK as EU citizens express confidence of their right to live and work in the UK. Bielewska (2012a) observed that young Polish migrants who arrived in the UK after Poland joined the European Union in 2004 stressed they have the full right to live and work there. They derived these rights not only from EU citizenship but also from the Second World War history when Polish pilots helped to win the Battle of Britain. The late -life migrants seem much less reflective. They do not use EU citizenship or WWII history to justify their right to stay. They just know that they have this right. They also feel needed. The interviews were conducted during the Brexit debate prior to the referendum but the late-life migrants, as with the earlier interviewees of White (2011), were convinced that Polish migrants are necessary for the British economy and did not worry about the Brexit referendum outcome:

Brexit is just noise about nothing. To mess up people's heads and cause fears. Because it's not possible that Poles will leave England. They [English people] will have a problem if Poles leave and the decision-makers know that they can't let Poles go because everything here would collapse. (Dorota, 60)

Polish late-life migrants are often economic migrants. They complain that due to their age they could not have found a job in Poland and working in the UK is their chance to make ends meet. Both men and women stress the fact that in the UK they are still employable, even though have turned 50 or 60 .

I came to England and they were happy that I want to work at my age. In Poland when I wanted to change my job they told me I was too old. And I wasn't a waitress, I was a senior accountant. (Dorota, 60 )

As well as the opportunity to work, late-life migrants appreciate England for the benefits offered to seniors. Three of them were clients of the Welcome Centre - an NGO that helps new immigrants learn about their rights. In contrast to the postwar migrants, they do not differentiate between different kinds of help and treat all financial support as their right. Received help makes them feel relaxed while their peers in Poland struggle: 
Because in Poland, I know looking at my sisters, it's a tragedy. They get 1600 [zloty] pension, after 40 years of work, and I send them money to buy pills. Here, I have everything free. It's a completely different life than in our homeland. (Maria, 65)

The less frequently mentioned benefit than free medicine is free transport within the UK, available to everyone over 60 . Some late-life migrants also receive housing benefit.

Summarizing, the senior migrants perceive their life in the UK as permanent and evaluate their economic situation as sufficient. They perceive themselves as too old for migration so a return to Poland is not an option. They compare living conditions in both countries only when prompted. Late-life migrants have moved recently and still count their profits and losses to make sure that living in the UK is a good decision. Both groups of migrants admit that the UK is a more seniorfriendly country than Poland.

\subsection{Attitudes toward the home country}

Both senior migrants and late-life migrants were born in Poland. However, the first group only spent their childhood and youth in Poland while the late-life migrants spent most of their adult life there. The attitude of the two groups towards their home country differs significantly.

\section{Senior migrants}

Since the post-war migrants could not visit their homeland for fear of prosecution, they reinvented their homeland abroad by forming a range of Polish institutions where they performed their national identities, from Polish churches, through schools and clubs to a Polish press and later also care homes (Bielewska 2012b). Although they can now visit Poland, it is no longer the homeland they have missed. As is typical for diasporic communities, they see their homeland as a mythical place of desire (...) a place of no return, even if it is possible to visit the geographical territory that is seen as the place of origin' (Brah, 1996: 192). The institutions of the Polish diasporic community are the places they turn to in search of the spirit of their lost homeland. It is also where they turn to for protection from being treated suspiciously by English people. The importance of Polish institutions for senior migrants is visible, amongst other things, in the popularity of Polish care homes. Even though they are often run by the church and too religious for the needs of some residents, they are perceived as a better option than an English care home. One of the residents explains:

Thanks to Father Jan and the nuns, I'm taken care of. I'm thankful to Father Jan that he visited me at home and brought me here. I don't complain about anything. I thank God 
that He sent me here so beautifully because otherwise I would have to live in the same type of home, but an English one. And you know how English people respect foreigners... [...] I'm very happy I'm among my own people. (Władka, 80)

After years of prosperity many Polish institutions, especially those outside London, have decayed due to the aging of their creators. The second generation is rarely interested in taking over their parents' heritage and the post-war migrants do not feel comfortable with the idea of passing their institutions to the newly arrived post-accession migrants. There is a rigid boundary between these groups (Bielewska, 2012b, Garapich, 2008). Participants of Bielewska's (2012a) research explain that new arrivals are "a completely different type of people than us" and "they bring us a bad name" (Bielewska, 2012a:155).

\section{Late-life migrants}

The late-life migrants are not a group that Polish institutions could be passed on to. Since they can go to Poland any time they do not express any need to consciously perform their Polish identity abroad (see White, 2011, Bielewska, 2012a). Late-life migrants can be divided into two main groups based on their attitudes to their home country: migrants who rationalize their stay abroad with a negative picture of their home country and those who believe their place is in Poland and express discomfort at living abroad.

Poland may be evaluated negatively in an absolute way, or relatively by comparison with England. The first situation shows migration as a reaction to push factors. It appears in the narrative of Zbyszek, who claims he left Poland when the PiS (Law and Justice Party) came to power:

I can't go back now, I wouldn't manage to live in Poland because I could do something bad. And I'm too old to fight, to go out in the streets, to protest. (Zbyszek, 60)

In the second situation, by finding more and more disadvantages of living in Poland, late-life migrants gain confidence that their decision to move was right. Presenting Poland as a worse place to live than the UK lets migrants position themselves as rational human beings.

There is also another group of migrants who are much less reflective and do not try to justify their stay abroad. To them describing their relationship with their homeland is difficult as this relationship feels 'obvious'. Talking about Poland, they express nostalgia for their homeland:

Agnieszka: What do you miss?

Maria: Everything. Poland. You can't say just one thing. Generally. I've left everything in Poland, you could say, there's nothing like being in your own country, at home [Polish "u siebie"]. (Maria, 65) 
This group expresses their belief that the importance of homeland grows with age. Poland is the country where they were born and lived all their life so it should also be their place later in life:

Maybe because I've lived so long, Poland pulls me back. I'm old, I spent all my life in Poland and it pulls me back. (Mirek, 60)

If we treat a country as home, this desire can be interpreted just as a wish of older people for aging in place. One of the common assumptions of gerontology is that aging people wish to stay in the place where they have spent most of their life (Peace et al., 2011; Wiles et al. 2011). Interestingly, in the case of this research, this nostalgia does not get translated into a decision to return. Migrants declare they would return if some undefined change for the better happens ("some improvement in Poland" in Maria's words), but they are unable to be precise about what this would be. They also develop an attachment to their new location:

I go to Poland and I don't want to come back. I come to England and it's hard for me to go to Poland. It's such difficult situation. (Maria, 65)

The time-anchored plans of return are drawn up by those late-life migrants who experience the vanishing of pull factors that brought them to the UK, i.e. the worsening of their work and life conditions:

(I)t became expensive. In the past you earned a bit less per hour but you could save a bit. Now you can't. Everything has got more expensive, including the flat. (Patrycja, 60)

Summarising, senior migrants see Poland as a mythical, desired yet unavailable place. The late-life migrants' relationship with their homeland is more complex. They need constantly repeated justification for their migration, therefore they describe Poland as a difficult place to live. However, if their conditions in the UK worsen, they are ready to consider returning.

\section{Summary}

This article has presented the experience of two groups of older Polish migrants in the UK: senior migrants aging in place and late-life migrants. The purpose of the paper was not to give a full typology of older Polish migrants in the UK but to signal that some assumptions about the migration of older people common among migration researchers are invalid and demand further investigation. Knowledge of the specificity of older migrants' experiences is increasingly important in forming successful migrant integration policies as the number of older migrants 
increases (Ciobanu et al., 2017). The experience and attitude of these two groups of older migrants' exposes several tacit and unfounded assumptions concerning older people and migration. The first tacit assumption present in the literature on Polish migration seems to be that older Poles do not migrate. Although European migration literature is increasingly concerned with late-life migrants, research into Polish migration has tended to focus on older migrants who have aged in place, presenting older people as immobile. This article has, however, shown that there is an active group of late-life migrants in their early 60s. Furthermore, these late-life migrants may be the primary migrants in their migration networks, joined later by their adult children.

The second assumption this article questions is that seniors should be analysed primarily from the perspective of the care regime (e.g. Kiełkowska et al., 2016, Kordasiewicz et al., 2017). This perspective excludes important spheres of life of the senior migrants, such as their participation in Polish community life, and is also largely irrelevant to the late-life migrants, who are mainly economic migrants. Their migration decision was the result of their economic situation. By moving abroad they achieved financial independence which is hardly accessible for most Polish pensioners. If at some point they are not able to work due to age related health problems, they benefit from the British welfare system which gives them the chance of further independent existence. Additionally, in leaving Poland, some of them also left behind Polish culture, with its age-related stereotypes, allowing them to enjoy more freedom in their lifestyle choices.

The next assumption concerns the vulnerability of older migrants. The research on aging in place treats discontinuity in place as essentially problematic with aging. Aging people are expected to demonstrate place attachment to their long-term residence and reluctance to change (Rowles et al., 2003 after Johansson, 2013). Additionally, older migrants are expected to suffer more loneliness than seniors from the host population as they do not have an extended family around them and their language competences are weaker. However, as critics observe, this conception does not recognise the fact that place is not a static container but a process that is marked with constant change (Cristoforetti et al., 2011, Wiles et al, 2011). Johansson (2013) observes that people may actively negotiate their relationships to the place. The senior migrants from my research are such an example. They complain of loneliness and their language skills deteriorate with age. However, these vulnerabilities are compensated by their strong ties to their ethnic community, built over years. Late-life migrants, who have had less time to form ties in their new place, surprisingly do not talk about loneliness. However, their aging in place needs to be understood in relation to the place they live in, which is not a bounded static place but rather a process (see Massey, 1992). Their place of life is not just their new geographical location but is produced out of processes of social interactions and may include social relations that are located in the places 
where the migrants are not physically present. Their economic status and their computer literacy allow them to cultivate transnational ties with friends and family left behind in Poland if they feel such need. Their reference group are their peers in Poland, therefore they see themselves as privileged as a result of migration. Their improved economic situation empowers them. The migration experience gives them many stimuli and they enjoy contacts with other migrants and locals. Maybe with time they will evaluate these contacts as shallow and insufficient - the way the post-war migrants do - however, at the moment they experience the first stage of migration - the fascination with strangeness and the satisfaction of social needs. Moreover, being abroad encourages some of them to enter new relationships which they might not have done in Poland. Even grandparents who come to look after their grandchildren avoid alienation. The grandmothers from my research opt for independent accommodation and this way they exercise their right to a private life. The vulnerability of late-life migrants may increase with time as their physical strength diminishes; however, at the moment they do not fit into the "vulnerable older migrant" category. An awareness of the internal diversity of older migrants and their migration strategies therefore needs to be built.

\section{References}

Baldassar L. (2008), Missing kin and longing to be together: emotions and the construction of co-presence in transnational relationships. Journal of intercultural studies, 29(3), 247-266.

Baldassar L. \& Merla L. (eds.), (2013), Transnational families, migration and the circulation of care: Understanding mobility and absence in family life, vol. 29. London/New York: Routledge.

Barglowski K., Krzyżowski Ł., \& Świątek P. (2015), Caregiving in Polish-German transnational social space: circulating narratives and intersecting heterogeneities. Population, Space and Place, 21(3), 257-269.

Becker G. (2003), Meanings of place and displacement in three groups of older immigrants. Journal of Aging Studies, 17(2), 129-149.

Bielewska A. (2012a), Changing Identities of Polishness: Post-War and Post-Accession Polish Migrants in Manchester, Oxford \& Bern: Peter Lang.

Bielewska A. (2012b), National Identities of Poles in Manchester: Modern and postmodern geographies, Ethnicities 12(1), 86-105.

Brah A. (1996), Carthographies of diaspora, London: Routledge.

Braun V. \& Clarke V. (2006), Using thematic analysis in psychology. Qualitative research in psychology, 3(2), 77-101.

Breuer T. (2005), Retirement migration or rather second-home tourism? German Senior Citizens on the Canary Islands. Dedicated to Jürgen Bähr on his 65th birthday. Die Erde: Zeitschrift der Gesellschaft für Erdkunde, 136(3), 313-333.

Burrell K. (2009), Introduction: Migration to the UK from Poland: Continuity and Change in East-West European Mobility, In: K. Burrell (ed.), Polish Migration to the UK in the 'New' European Union After 2004, Surrey: Ashgate, 1-19.

Ciobanu R.O. \& Fokkema T. (2017), The role of religion in protecting older Romanian migrants from loneliness, Journal of Ethnic and Migration Studies, 43(2), 199-217. 
Ciobanu R.O., Fokkema T., Nedelcu M. (2017), Ageing as a migrant: vulnerabilities, agency and policy implications, Journal of Ethnic and Migration Studies, 43(2), 164-181.

Cristoforetti A., Gennai F., Rodeschini G. (2011), Home sweet home: The emotional construction of places. Journal of Aging Studies 25(3), 225-232.

Datta A. (2008), Building differences: material geographies of home(s) among Polish builders in London. Transactions of the Institute of British Geographers, 33(4), 518-531.

de Jong Gierveld J., van der Pas S., Keating N. (2015), Loneliness of Older Immigrant Groups in Canada: Effects of Ethnic-Cultural Background. Journal of CrossCultural Gerontology, 30 (3), 251-268.

Edensor T. (2006), Reconsidering National Temporalities. Institutional Times, Everyday Routines, Serial Spaces and synchronicities. European Journal of Social Theory, 9(4), 525-545.

Faist T. (1996), Immigration, Integration, and the Welfare State: Germany and the USA in a Comparative Perspective. Public policy and social welfare, 21, 227-258.

Fokkema T., \& Naderi R. (2013), Differences in Late-Life Loneliness: A Comparison between Turkish and Native-Born Older Adults in Germany. European Journal of Ageing, 10(4), 289-300.

Garapich M.P. (2008), Odyssean refugees, migrants and power: Construction of the 'other' and civic participation within the Polish community in the United Kingdom, In: D. Reed-Danahay \& C.B. Brettell (eds.), Citizenship, political engagement and belonging: Immigrants in Europe and the United States. New Brunswick: Rutgers University Press, 124-144.

Granovetter M.S. (1973), The strength of weak ties. American Journal of Sociology, 78(6), 13601380.

Horn V. \& Schweppe C. (eds.), (2016), Transnational Aging: Current Insights and Future Challenges. London/New York: Routledge.

Johansson K., Laliberte Rudman D., Mondaca M., Park M., Luborsky M., Josephsson S., Asaba E. (2013), Moving beyond 'aging in place'to understand migration and aging: Place making and the centrality of occupation. Journal of occupational science, 20(2), 108-119.

Kałuża-Kopias D. (2015), Polscy emigranci w późnym wieku [Polish emigrant in later age]. Acta Universitatis Lodziensis Folia Oeconomica, 4(315), 55-69.

Karl U., \& Torres, S. (eds.) (2016), Ageing in Contexts of Migration. London/New York: Routledge.

Kiełkowska M, Jaźwińska E., Kloc-Nowak W., Kordasiewicz, A., \& Radziwinowicz A., (2016), Przepływy opieki między migrantami i ich starzejącymi się rodzicami - metoda badawcza i przykład jej zastosowania [Flows of Care between Migrants and Their Aging Parents A Research Method and an Example of its implementation], Studia Migracyjne- Przeglad Polonijny, 161(3), 345-368.

Kilkey M., Merla L. (2014), Situating transnational families' care-giving arrangements: the role of institutional contexts. Global Networks, 14(2), 210-229.

Kordasiewicz A., Radziwinowiczówna A., Kloc-Nowak W. (2017), Ethnomoralities of care in transnational families: care intentions as a missing link between norms and arrangements. Journal of Family Studies, 1-18, https://doi.org/10.1080/13229400.2017.1347516

Krzyżowski Ł. (2013), Polscy migranci $i$ ich starzejący się rodzice. Transnarodowy system opieki międzygeneracyjnej. Warszawa: Wydawnictwo Naukowe Scholar.

Krzyżowski Ł., Slany K., Ślusarczyk M. (2017), Care Issues in the Transnational Families. A Polish Research Review. Polish Sociological Review, 199(3), 367-385.

Kvale S. (1996), Interviews. An introduction to qualitative research interviewing. Thousand Oaks, CA: Sage. 
Lewis D.C. (2009), Aging out of place: Cambodian refugee elders in the United States. Family and Consumer Sciences Research Journal, 37(3), 376-393.

Lopez Rodriguez M. (2010), Migration and a quest for 'normalcy'. Polish migrant mothers and the capitalization of meritocratic opportunities in the UK, Social identities, 16 (3), 339-358.

Massey D. (1992), 'A Place Called Home.' New Formations, 17, 3-15.

Office for National Statistics (2017), Living abroad: migration between Britain and the EU8, https://www.ons.gov.uk/peoplepopulationandcommunity/populationandmigration/internationalmigration/articles/livingabroad/migrationbetweenbritainandtheeu8 [Accessed: 5.10.2017]

Okólski M., \& Salt J. (2014), Polish emigration to the UK after 2004; why did so many come? Central and Eastern European Migration Review, 3(2), 11-37.

Ono M. (2008), Long-stay tourism and international retirement migration: Japanese retirees in Malaysia. Transnational Migration in East Asia Senri Ethnological Reports 77: 151-162

Peace S., Holland C., Kellaher L. (2011), Option recognition in later life: Variations in ageing in place. Ageing \& Society, 31(5): 734-757.

Pemberton S., \& Scullion L. (2013), The policies and politics of managed migration: Exploring mature labour migration from Central and Eastern Europe into the UK. Journal of Ethnic and Migration Studies, 39, 443-461.

Plaza D. (2000), Transnational Grannies: The Changing Family Responsibilities of Elderly

African Caribbean-Born Women Resident in Britain, Social Indicators Research, 51(1), 75-105.

Pustułka P. (2015), Virtual transnationalism: Polish migrant families and new technologies, Studia Migracyjne-Przeglad Polonijny, 41(3), 99-122.

Putnam R.D. (2007), E Pluribus Unum: Diversity and Community in the Twenty-First Century. The 2006 Johan Skytte Prize Lecture, Scandinavian Political Studies, 30(2), 137-174.

Raghuram P. (2004), The difference that skills make: gender, family migration strategies and regulated labour markets, Journal of ethnic and migration studies, 30(2), 303-321.

Rowles G.D., Oswald F., Hunter E.G. (2003), Interior living environments in old age. In: Wahl HW, Scheidt RJ, Windley PG (eds). Annual review of gerontology and geriatrics: Focus on aging in context: Sociophysical environment. New York, NJ: Springer, 167-194.

Ryan L., Klekowski von Koppenfels A., Mulholland J. (2015), “The Distance between Us”: A Comparative Examination of the Technical, Spatial and Temporal Dimensions of the Transnational Social Relationships of Highly Skilled Migrants.' Global Networks 15(2), 198-216.

Ryan L., Sales R., Tilki M., Siara B. (2008), Social Networks, Social Support and Social Capital: The Experiences of Recent Polish Migrants in London. Sociology, 42(4), 672-690.

Scragg T. (1986), The Polish community in Manchesterand the North West, Unpublished Master dissertation, Manchester Polytechnic, Manchester.

Saldaña J. (2012), The Coding Manual for Qualitative Researchers. Los Angeles: Sage Publishing House.

Staręga-Piasek J., Lisowski A., Suchecka J. (1985), Starość psychospołeczna i potrzeby opieki medycznej ludzi starych, Warszawa: Szkoła Główna Planowania i Statystyki.

Szukalski P. (2014), Wiek przechodzenia na emeryturę w Polsce, Demografia i Gerontologia Społeczna - Biuletyn Informacyjny 8, Zakład Demografii UŁ.

Temple B. (2001), Polish families: A narrative approach, Journal of Family, 22, 386-399.

van den Broek T., \& Grundy E. (2017), Loneliness among Polish migrants in the Netherlands: The impact of presence and location of partners and offspring, Demographic Research, 37(23), 727-742. 
Urbańska S. (2016), Transnational Motherhood and Forced Migration. Causes and Consequences of the Migration of Polish Working-Class Women 1989-2010. Central and Eastern European Migration Review, 5(1), 109-128.

Vullnetari J., \& King R. (2008). 'Does your granny eat grass?'On mass migration, care drain and the fate of older people in rural Albania. Global Networks, 8(2), 139-171.

Walsh K., \& Näre L. (eds.) (2016), Transnational Migration and Home in Older Age, London/ New York: Routledge.

Warnes A. M., \& Williams A. (2006), Older migrants in Europe: a new focus for migration studies, Journal of Ethnic and Migration Studies, 32(8), 1257-1281.

Warnes A.M., Friedrich K., Kellaher L., Torres, S. (2004), The diversity and welfare of older migrants in Europe. Ageing \& Society, 24(3), 307-326.

White A. (2011), Polish Families and Migration since EU Accession, Bristol: Policy Press.

Wiles J.L., Leibing A., Guberman N., Reeve J., Allen R.E.S. (2011), The meaning of "aging in place" to older people. The Gerontologist 52(3): 357-366. 